\title{
Development of chick retina cells in culture: cobalt entry through AMPA receptors and expression of GluR4 AMPA receptor subunit
}

\author{
Armando J. Cristóvão, Caetana M. Carvalho* \\ Center for Neuroscience of Coimbra, Department of Zoology, University of Coimbra, Coimbra, Portugal
}

Accepted 15 October 2002

\begin{abstract}
The functionality of $\alpha$-amino-3-hydroxy-5-methylisoxazole-4-propionate (AMPA) receptors in chick embryo retina cells during development in vitro was studied by using $\mathrm{Co}^{2+}$ uptake, and these data were correlated with the expression of the AMPA receptor subunit GluR4. We found that at $5 \mathrm{~h}$ in vitro only a small number of cells took up $\mathrm{Co}^{2+}$ upon stimulation with $100 \mu \mathrm{M}$ kainate or other AMPA receptor agonists, in the presence of cyclothiazide (CTZ), to inhibit desensitisation. The number of cells sensitive to kainate increased from $5 \mathrm{~h}$ in vitro to 3 days in vitro (DIV), and remained relatively constant until $14 \mathrm{DIV}$. When the cells were stimulated with $(2 S, 4 S)$-4-methylglutamic acid $(30 \mu \mathrm{M})$, a specific kainate receptor agonist, after inhibiting desensitisation with concanavalin A, we did not observe an increase in the number of cells responding, as compared to the control. The expression of the AMPA receptor subunit GluR4 during development was detected by immunofluorescence mainly at the perinuclear region of the cells, and the number of positive cells increased from $5 \mathrm{~h}$ in vitro to 7 DIV, and remained relatively constant until 14 DIV. The results suggest that AMPA receptors can be functionally active at early embryonic stages ( $5 \mathrm{~h}$ in vitro) in cultured retinal neurons, although in only a few cells, before synapse formation (E12). The localisation of GluR4 was well correlated with $\mathrm{Co}^{2+}$ entry, since the strongest GluR4 immunoreactivity was found in the regions that showed the most intense labelling with $\mathrm{Co}^{2+}$. Finally, we found that the expression levels of GluR4 at the neurites increased between $5 \mathrm{~h}$ in vitro and $7 \mathrm{DIV}$, near the period of synapse formation.
\end{abstract}

(C) 2002 Elsevier Science B.V. All rights reserved.

Theme: Neurotransmitters, modulators, transporters and receptors

Topic: Excitatory amino acid receptors: structure, function and expression

Keywords: Retina; Chick; AMPA receptor; GluR4; Development; Cobalt; Non-NMDA receptor

\section{Introduction}

Glutamate is the major excitatory neurotransmitter in the retina, where it acts mainly by activating ionotropic glutamate receptors [4]. In the CNS, these receptors are known to play a role in development [24], neuronal plasticity [23], dendritic spine modulation [32], neuronal

\footnotetext{
Abbreviations: AMPA, $\alpha$-amino-3-hydroxy-5-methylisoxazole-4-propionate; Con A, concanavalin A; CTZ, cyclothiazide; DIV, days in vitro; GluR4, glutamate receptor subunit 4; NMDA, $N$-methyl-D-aspartate; MGA, $(2 S, 4 S)$-4-methylglutamic acid

*Corresponding author. Tel.: +351-239-822-752; fax: +351-239-822776.

E-mail address: cmcarv@cnc.cj.uc.pt (C.M. Carvalho).
}

cell death [10] and in survival of different neuronal cell types [2]. Ionotropic glutamate receptors can be divided according to their molecular structure, sensitivity to agonists, and physiological properties into $\alpha$-amino-3-hydroxy5-methylisoxazole-4-propionate (AMPA), kainate $[3,5,12,36]$ and $N$-methyl-D-aspartate (NMDA) receptors [12]. AMPA receptors are oligomeric structures formed by the different combinations of GluR1-4 subunits [6,21,25], and these subunits were also cloned in the chick brain [26]. Several subunits of the kainate receptors have been identified, the GluR5-7 and KA1-2 [20,30].

Several authors have proposed that the ionotropic glutamate receptors, including AMPA receptors, are important in neuronal plasticity on dendritic spines [16,32]. More recently, it has been proposed that the transient expression 
of the AMPA receptor subunit GluR4 in rat hippocampus is important in the spontaneous electric activity [35]. Also, studies from our laboratory have shown the importance of glutamate receptors in modulating $\left[\mathrm{Ca}^{2+}\right]_{\mathrm{i}}$, as well as neurotransmitter release, in cultured embryonic chick retina cells $[8,9,13-15]$. Since $\left[\mathrm{Ca}^{2+}\right]_{\mathrm{i}}$ is an important second messenger, it is of interest to determine the $\mathrm{Ca}^{2+}$ permeability of AMPA receptors during development, as mimicked by $\mathrm{Co}^{2+}$ uptake, which permits determining the expression and localisation of the AMPA receptor subunit GluR4.

\section{Materials and methods}

\subsection{Materials}

Fetal calf serum was from Biochrom (Berlin, Germany). PVDF membranes, ECF and the secondary antibody conjugated with alkaline phosphatase were from Amersham (Buckinghamshire UK). The anti-GluR4 antibody against GluR4 (60666 N) was from BD Pharmingen (San Diego, CA, USA). Prolong antiFade kit, Alexa conjugated secondary antibodies Alexa 488 and Alexa 495 were from Molecular Probes (Leider, Hillard, USA). All other reagents, including anti-MAP2, were from Sigma-Aldrich (St. Louis, MO, USA), or from Merck (Darmstadt, Germany). White Leghorn eggs were obtained from a local hatchery.

\subsection{Cell culture}

Primary cultures of chick retinal neurons, from 8-dayold chick embryos, were prepared as previously described [11]. After dissociation, the viability of the cells was greater then $95 \%$, as estimated by Trypan blue dye exclusion. After cell isolation and appropriate dilution, cells were plated at a density of $0.4 \times 10^{6} \mathrm{cells} / \mathrm{cm}^{2}$, on glass coverslips, coated with poly-D-lysine $(0.1 \mathrm{mg} / \mathrm{ml})$, on 12-multiwell plates. The cells were maintained in culture at $37^{\circ} \mathrm{C}$, in a humidified atmosphere of $95 \%$ air-5\% $\mathrm{CO}_{2}$ before experiments.

\subsection{Cobalt uptake experiments}

Cells with different times in culture were stimulated in different conditions, as indicated in the figure captions. Cultured cells were rinsed twice with saline buffer (in $\mathrm{mM}$ : $132 \mathrm{NaCl}, 4 \mathrm{KCl}, 6$ glucose, 20 HEPES, $0.7 \mathrm{MgCl}_{2}$, $0.5 \mathrm{CaCl}_{2}$, at $\mathrm{pH} 7.4$ ) and were then incubated in the same solution supplemented with $5 \mathrm{mM} \mathrm{CoCl}$, and with different stimuli, for $20 \mathrm{~min}$. The stimuli used were: 100 $\mu \mathrm{M}$ AMPA, $10 \mu \mathrm{M}$ or $100 \mu \mathrm{M}$ AMPA in the presence of $30 \mu \mathrm{M}$ cyclothiazide (CTZ), $30 \mu \mathrm{M}$ kainate, $10 \mu \mathrm{M}$ or 30 $\mu \mathrm{M}(2 S, 4 S)$-4-methylglutamic acid (MGA) in the presence of $0.3 \mathrm{mg} / \mathrm{ml}$ concanavalin A (con A), $500 \mu \mathrm{M}$ glutamate,
$500 \mu \mathrm{M}$ glutamate plus $30 \mu \mathrm{M}$ CTZ or $100 \mu \mathrm{M}$ NMDA. In order to stop cobalt uptake, saline buffer with cobalt was removed by gentle aspiration and the cells were washed twice, by incubation for $5 \mathrm{~min}$ and $10 \mathrm{~min}$ with saline buffer containing $2 \mathrm{mM}$ EDTA. All procedures were carried out at room temperature. The cells were immediately processed for precipitation and enhancement of cobalt staining.

\subsection{Precipitation and enhancement of cobalt staining}

The precipitation and enhancement of cobalt staining of the cells on the coverslips was performed as described by Jensen et al. with minor modifications [22]. The cobalt was precipitated by incubating the coverslips with $0.12 \% \mathrm{Na}_{2} \mathrm{~S}$ in saline buffer, for $5 \mathrm{~min}$. The cells were washed in saline buffer and then fixed in $4 \%$ paraformaldehyde, containing $4 \%$ sucrose in phosphate buffered saline (PBS, in $\mathrm{mM} ; 137$ $\mathrm{NaCl}, 2.7 \mathrm{KCl}, 10 \mathrm{Na}_{2} \mathrm{HPO}_{4}, 12 \mathrm{H}_{2} \mathrm{O}, 1.8 \mathrm{KH}_{2} \mathrm{PO}_{4}, \mathrm{pH}$ 7.4) for $30 \mathrm{~min}$ at room temperature. Enhancement of $\mathrm{CoS}$ precipitate was performed after cell washing with warm $\left(50{ }^{\circ} \mathrm{C}\right)$ developing buffer (in $\mathrm{mM}$ : 292 sucrose, 15.5 hydroquinone and 42 citric acid), in warm developing buffer with $1 \mathrm{mg} / \mathrm{ml} \mathrm{AgNO}_{3}$, for $1 \mathrm{~h}$ in dark conditions. To terminate the staining, cells were washed in warm developing buffer. Cells were then incubated for $5 \mathrm{~min}$ in $5 \%$ sodium thiosulfate, at room temperature, to enhance staining. The cells were finally washed twice in PBS and the coverslips were mounted on Entellan. The stained cells were counted on a Leica microscope, coupled to a photomicrograph system, in 9-12 arbitrary fields, and photomicrographs were taken for illustrative situations.

\subsection{Immunofluorescence staining}

Chick retina cells with different times in culture were washed in PBS and fixed with $2 \%$ paraformaldehyde and 4\% sucrose, in PBS, for $30 \mathrm{~min}$. After washing the cells twice with PBS, the cells were permeabilised for $5 \mathrm{~min}$ in $1 \%$ Triton X-100 in PBS, and blocked for $1 \mathrm{~h}$ with $0.2 \%$ gelatin and $0.2 \%$ Tween 20, in PBS. The retina cells were then incubated for $2 \mathrm{~h}$ with the rabbit polyclonal antiGluR4, diluted 1:200, and with the mouse anti-MAP2, diluted 1:400, in PBS, supplemented with $0.2 \%$ Tween-20 and $0.1 \%$ gelatin. Following this incubation the cells were rinsed for $5 \mathrm{~min}$ in three changes of $0.1 \%$ Tween-20 and $0.1 \%$ gelatin, in PBS. These cells were further incubated for $1 \mathrm{~h}$, in dark conditions, simultaneously with the antirabbit Alexa 488, diluted 1:200, and with the anti-mouse Alexa 594, diluted 1:200, in PBS supplemented with $0.2 \%$ Tween 20 and $0.1 \%$ gelatin. The coverslips were rinsed again as before, and were mounted with the Prolong ${ }^{\mathrm{TM}}$ antifade Kit from Molecular Probes, to reduce photobleaching of fluorescent dyes. All procedures were carried out at room temperature, and the cells were kept at $-20{ }^{\circ} \mathrm{C}$ until fluorescence analysis. Cell fluorescence labelling was 
visualised in a MRC600 confocal imaging system (BioRad, Milan, Italy) linked to a Nikon Optiphot-2 fluorescence microscope. A krypton-argon mixed laser was used in a combination with a 488-nm bandpass filter (excitation) and a 585-nm long-pass filter (emission), to examine GluR4 (Alexa 488) labelling. To visualise MAP2 (Alexa 594) labelling we used a 568-nm bandpass filter (excitation) and a 585-nm long-pass filter (emission). Imaging processing was performed using CONFOCAL ASSISTANT software (Bio-Rad). Control experiments consisted in the omission of the primary antibodies from the incubation, and resulted in no specific staining.

\subsection{Statistical analysis}

Results are presented as mean \pm S.E.M of two experiments. Cells were counted in nine randomly chosen fields in each coverslip $(n=18)$, at a $400 \times$ magnification (mag.). The results were analysed using one-way ANOVA. Differences between treatments were determined using the Tukey-Kramer multiple comparisons test.

\section{Results}

\section{1. $\mathrm{Co}^{2+}$ uptake upon glutamate stimulation of chick retina cells during development in culture}

The $\mathrm{Co}^{2+}$ uptake, in response to stimulation of chick retina cells with different ionotropic glutamate receptor agonists, was examined at five developmental ages in stationary (monolayer) cultures. The ages tested correspond to embryos with 8 days (day of cell isolation) plus the number of days in vitro (DIV).

We found that under control condition, where cells were submitted to all $\mathrm{Co}^{2+}$ processing, in the absence of stimulation with glutamate receptor agonists, there were almost no stained cells (Fig. 1). This scarce staining was found at $5 \mathrm{~h}$ in culture and for 3, 7, 10 and 14 DIV as well, and the cell response type is represented in Fig. 2A and B, at $5 \mathrm{~h}$ in vitro and $14 \mathrm{DIV}$, respectively, but are representative of all other stages. Also, the presence of $30 \mu \mathrm{M} \mathrm{CTZ}$ or $0.3 \mathrm{mg} / \mathrm{ml}$ con A were tested under control conditions, and the results were not statistically different from the control, indicating that the cells could not be affected by the presence of these drugs (data not shown).

In chick retina cells stimulated with $500 \mu \mathrm{M}$ glutamate, the number of responding cells was relatively small and remained low during development (Fig. 1). This response is somewhat higher than that found in the control, for each stage $(P>0.05)$, but different for the situations of glutamate or AMPA in the presence of CTZ or kainate $(P$ values summarised in Table 1). The response type of the cells was localised at the cell body, as we can see for 14 DIV (Fig. 2D) and may be representative for all other stages also with the representative image for 3 DIV cells

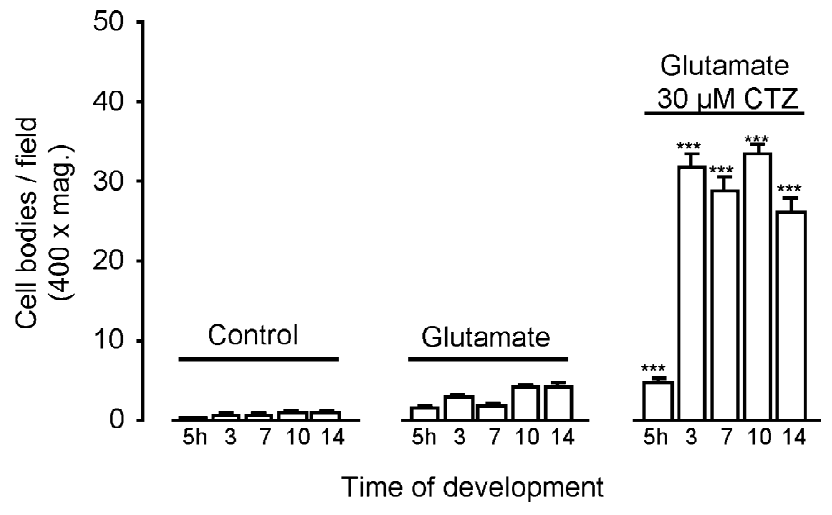

Fig. 1. Chick retina cells with cobalt positive response in the absence of stimulus (control) or upon stimulation with glutamate, during development in vitro for $5 \mathrm{~h}, 3,5,7,10$ and 14 days. Cobalt uptake in the absence or the presence of stimulus $(500 \mu \mathrm{M}$ glutamate, or $500 \mu \mathrm{M}$ glutamate and $30 \mu \mathrm{M} \mathrm{CTZ)} \mathrm{was} \mathrm{determined} \mathrm{as} \mathrm{described} \mathrm{in} \mathrm{Materials} \mathrm{and}$ methods. Significantly different from control; ***, $P<0.001$.

with AMPA stimulation (Fig. 2C). Upon stimulation with $500 \mu \mathrm{M}$ glutamate, in the presence of $30 \mu \mathrm{M} \mathrm{CTZ}$, the number of $\mathrm{Co}^{2+}$ positive cells increased from $5 \mathrm{~h}$ in vitro to $3 \mathrm{DIV}$, and remained relatively constant for the rest of the period of development in vitro, up to 14 DIV (Fig. 1, $P<0.001$ as compared with control, see also Table 1 for multiple comparisons). The response type of the cells may be represented by the images in Fig. 2F (3 DIV, stimulation with $100 \mu \mathrm{M}$ AMPA+30 $\mu \mathrm{M}$ CTZ) or in Fig. $2 \mathrm{H}(14$ DIV, stimulation with kainate). We also found at 7 DIV, that the response to stimulation with $100 \mu \mathrm{M}$ glutamate plus $30 \mu \mathrm{M}$ CTZ $(32.75 \pm 2.93$ cell bodies/field $400 \times$ mag.) was not different from the results obtained when the cells were stimulated with $500 \mu \mathrm{M}$ glutamate plus $30 \mu \mathrm{M}$ CTZ ( $P>0.05$, Fig. 1).

\section{2. $\mathrm{Co}^{2+}$ uptake upon AMPA receptor activation of chick retina cells during development in culture}

When chick retina cells were stimulated with $100 \mu \mathrm{M}$ AMPA (Fig. 3), there was a significant increase in the number of $\mathrm{Co}^{2+}$-positive cells, as compared to the nonstimulated cells, except for 3 and 7 DIV (Fig. 3, Table 1), and the responses were maintained during development. The uptake of $\mathrm{Co}^{2+}$ was observed mainly at the cell body at all developmental stages, as visualised for 3 DIV Fig. $2 \mathrm{C}$, but representative for all stages. At 7 DIV, the number of $\mathrm{Co}^{2+}$ positive cells was the same when the cells were stimulated with $100 \mu \mathrm{M}$ AMPA (Fig. 3) or $400 \mu \mathrm{M}$ AMPA (5.27 \pm 0.44 cell bodies/field $400 \times$ mag., $P>0.05$ ).

The number of positive cells observed upon stimulation of chick retina cells with $10 \mu \mathrm{M}$ AMPA, in the presence of $30 \mu \mathrm{M} \mathrm{CTZ}$, an inhibitor of AMPA receptor desensitisation [34], increased dramatically from $5 \mathrm{~h}$ in culture to 3 DIV and remained constant thereafter until 14 DIV (Fig. 

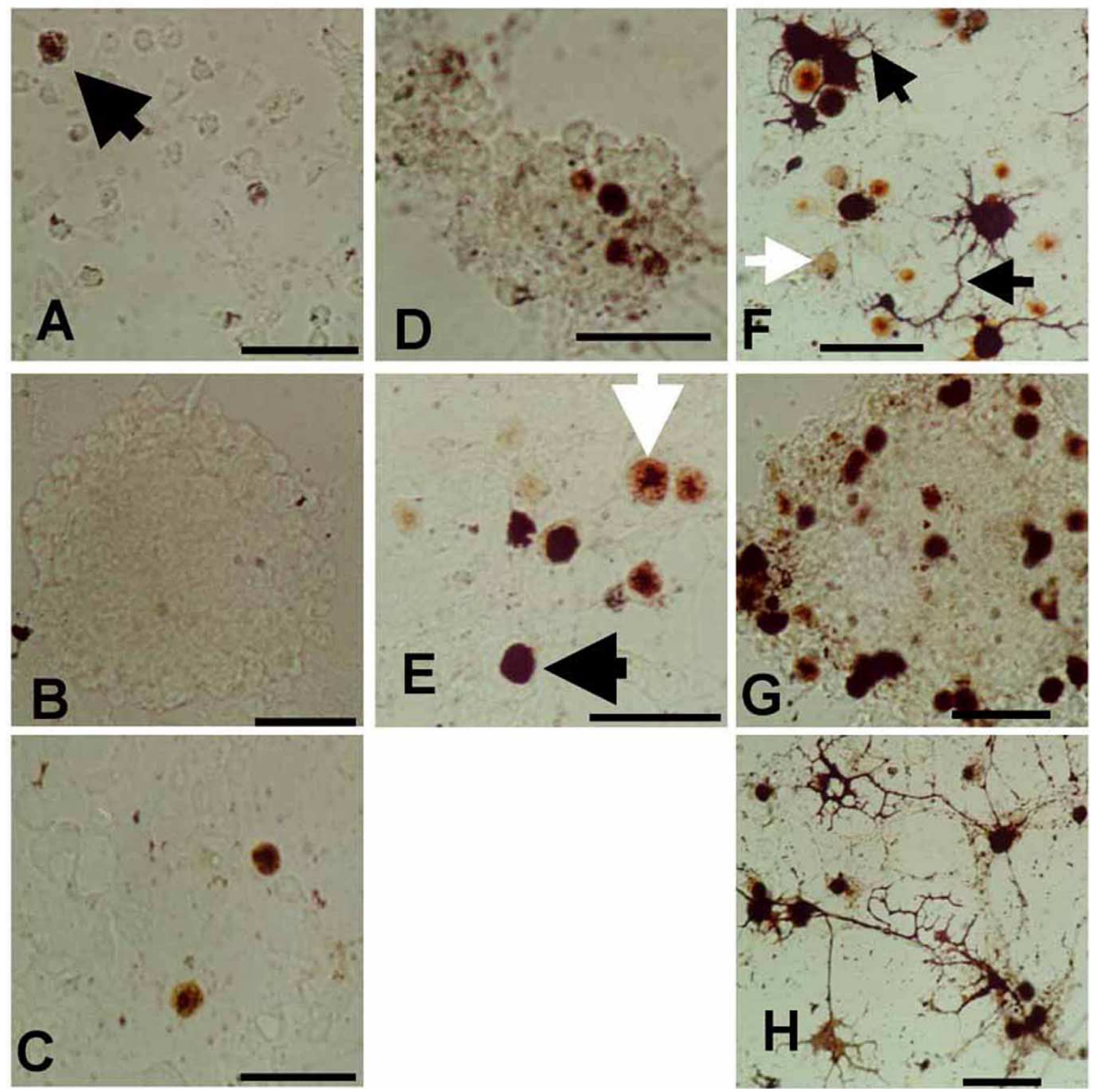

Fig. 2. Representative microphotographs of chick retina cultures illustrative of cobalt staining, during development in vitro for 5 h, 3, 5, 7, 10 and 14 days. (A) Cells with $5 \mathrm{~h}$ in vitro, in the absence of stimulus. Occasionally some cells were positive, as pointed by arrow (this type of positive response was observed for all control situations). (B) Cells with 14 DIV, in the absence of stimulus. Picture taken near the centre of the coverslip. (C) Cells with 3 DIV upon stimulation with $100 \mu \mathrm{M}$ AMPA. Similar responses are obtained for stimulation with NMDA, MGA or glutamate, at the same stage of development. (D) Cells with 14 DIV upon stimulation with $500 \mu \mathrm{M}$ glutamate, but similar responses are obtained for other situations (NMDA, MGA, AMPA), at the

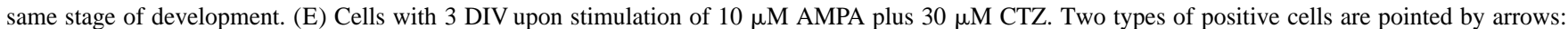
the white arrow indicates a cell responding with low intensity and the black arrows indicate a cell which responds intensively. (F) Cells with 3 DIV upon stimulation of $100 \mu \mathrm{M}$ AMPA plus $30 \mu \mathrm{M}$ CTZ. Two types of positive cells are pointed by arrows: white arrow indicates a cell responding with low intensity and the black arrows indicate cells with stained neurites and intensive response. This response type is also representative of other situations (kainate, glutamate plus CTZ) at the same stages of development. (G) Cells with 14 DIV upon stimulation of $100 \mu$ M AMPA plus $30 \mu M$ CTZ. This response type is also representative of other situations (kainate, glutamate plus CTZ) at the same stages of development. (H) Cells with 14 DIV upon stimulation of $100 \mu \mathrm{M}$ kainate. This response type is also representative of other situations (AMPA plus CTZ, glutamate plus CTZ), at the same stages of development. Photographs are representative of the situations quantified in Figs. 1, 3-5. Scale bar, $50 \mu \mathrm{M}$. 
Table 1

Statistical analysis ( $P$ values) for $\mathrm{Co}^{2+}$ uptake due to AMPA stimulation in comparison with other conditions of stimulation, as indicated, for different times of development in vitro

\begin{tabular}{|c|c|c|c|c|c|}
\hline \multirow[t]{2}{*}{ Comparison } & \multicolumn{5}{|c|}{ Time of development in vitro } \\
\hline & $5 \mathrm{~h}$ & 3 days & 7 days & 10 days & 14 days \\
\hline 100 AMPA vs. 10 AMPA +CTZ & Ns & 0.001 & 0.001 & 0.001 & 0.001 \\
\hline 100 AMPA vs. 100 AMPA+CTZ & 0.001 & 0.001 & 0.001 & 0.001 & 0.001 \\
\hline 100 AMPA vs. $10 \mathrm{MGA}+\mathrm{Con} \mathrm{A}$ & Ns & Ns & Ns & Ns & Ns \\
\hline 100 AMPA vs. $30 \mathrm{MGA}+$ Con A & Ns & Ns & Ns & Ns & Ns \\
\hline 100 AMPA vs. kainate & Ns & 0.001 & 0.001 & 0.001 & 0.001 \\
\hline 100 AMPA vs. 500 glu & Ns & Ns & Ns & Ns & Ns \\
\hline 100 AMPA vs. $500 \mathrm{glu}+\mathrm{CTZ}$ & Ns & 0.001 & 0.001 & 0.001 & 0.001 \\
\hline $10 \mathrm{AMPA}+\mathrm{CTZ}$ vs. $100 \mathrm{AMPA}+\mathrm{CTZ}$ & 0.001 & 0.001 & 0.01 & Ns & Ns \\
\hline $10 \mathrm{AMPA}+\mathrm{CTZ}$ vs. kainate & Ns & 0.001 & Ns & 0.001 & 0.001 \\
\hline $10 \mathrm{AMPA}+\mathrm{CTZ}$ vs. $10 \mathrm{MGA}+\mathrm{Con} \mathrm{A}$ & Ns & 0.001 & 0.001 & 0.001 & 0.001 \\
\hline $10 \mathrm{AMPA}+\mathrm{CTZ}$ vs. $30 \mathrm{MGA}+\mathrm{Con} \mathrm{A}$ & Ns & 0.001 & 0.001 & 0.001 & 0.001 \\
\hline $10 \mathrm{AMPA}+\mathrm{CTZ}$ vs. $500 \mathrm{glu}$ & Ns & 0.001 & 0.001 & 0.001 & 0.001 \\
\hline 10 AMPA+CTZ vs. 500 glu + CTZ & 0.001 & Ns & Ns & 0.001 & Ns \\
\hline $100 \mathrm{AMPA}+\mathrm{CTZ}$ vs. kainate & 0.001 & Ns & Ns & Ns & 0.01 \\
\hline $100 \mathrm{AMPA}+\mathrm{CTZ}$ vs. $10 \mathrm{MGA}+\mathrm{Con} \mathrm{A}$ & 0.001 & 0.001 & 0.001 & 0.001 & 0.001 \\
\hline $100 \mathrm{AMPA}+\mathrm{CTZ}$ vs. $30 \mathrm{MGA}+\mathrm{Con} \mathrm{A}$ & 0.001 & 0.001 & 0.001 & 0.001 & 0.001 \\
\hline $100 \mathrm{AMPA}+\mathrm{CTZ}$ vs. $500 \mathrm{glu}$ & 0.001 & 0.001 & 0.001 & 0.001 & 0.001 \\
\hline $100 \mathrm{AMPA}+\mathrm{CTZ}$ vs. $500 \mathrm{glu}+\mathrm{CTZ}$ & 0.001 & 0.001 & Ns & Ns & $\mathrm{Ns}$ \\
\hline
\end{tabular}

Concentrations are in $\mu \mathrm{M}$. Glutamate, glu.

3 ). The response of the 3 DIV cells in these conditions is mainly concentrated at the cell body (Fig. 2E), and this image is representative for cultures at all stages. However, for cultures older then 7 DIV we could observe some cells responding like those with 14 DIV cultures, stimulated with kainate (Fig. 2H).

When the cells were stimulated with $100 \mu \mathrm{M}$ AMPA in the presence of $30 \mu \mathrm{M} \mathrm{CTZ}$, we found a dramatic increase in the number of cells responding from $5 \mathrm{~h}$ in vitro to 3 DIV, and thereafter a slight decrease was found until 14 DIV (Fig. 3). The number of positive cells was significantly higher than that observed in control or with stimulation with $100 \mu \mathrm{M}$ AMPA $(P>0.001)$. The type of

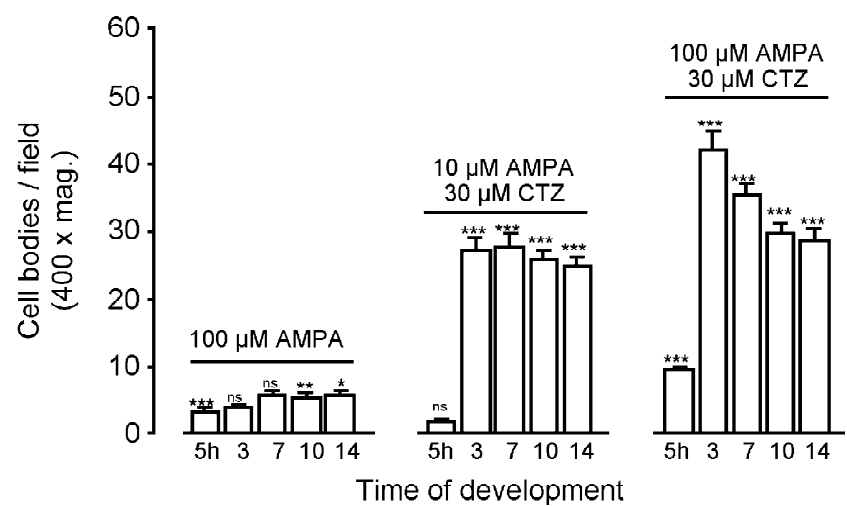

Fig. 3. Chick retina cells with cobalt positive response upon AMPA stimulation during development in vitro for $5 \mathrm{~h}, 3,5,7,10$ and 14 days. Cobalt uptake under stimulation with $100 \mu \mathrm{M}$ AMPA, $10 \mu \mathrm{M}$ AMPA plus $30 \mu \mathrm{M}$ CTZ or $100 \mu \mathrm{M}$ AMPA plus $30 \mu \mathrm{M}$ CTZ was determined as described in Materials and methods section. Significantly different from control, in the absence of stimulation (Fig. 1), $*, P<0.05, * *, P<0.01$ and $* * *, P<0.001$. Not significantly different from control (Fig. 1), Ns. response of cells at $3 \mathrm{DIV}$ is represented in Fig. $2 \mathrm{~F}$, and cells with $\mathrm{Co}^{2+}$ labelled neurites is representative for older cultures, as well as shown in Fig. 2G.

\section{3. $\mathrm{Co}^{2+}$ uptake upon kainate receptor activation of chick retina cells during development in culture}

When chick retina cells were stimulated either with 10 $\mu \mathrm{M}$ or $30 \mu \mathrm{M}$ MGA, an agonist of kainate receptors [17], in the presence of con $\mathrm{A}$, an inhibitor of kainate receptor desensitisation [33], there was almost no increase in the number of cells that accumulate $\mathrm{Co}^{2+}$, relatively to the control (Fig. 4). The uptake of $\mathrm{Co}^{2+}$ under these conditions occurred mainly at the cell body, similar to the responses represented for $3 \mathrm{DIV}$, upon stimulation with AMPA (Fig. 2C) and for 14 DIV upon stimulation with glutamate (Fig. 2D).

When the cells were stimulated with $100 \mu \mathrm{M}$ kainate there was a dramatic increase in the number of cells that took up $\mathrm{Co}^{2+}$, in cultures older than 3 DIV (Fig. 4). At 7 DIV the effect of $30 \mu \mathrm{M}(31.79 \pm 1.98$ cell bodies/field $400 \times$ mag.) or $100 \mu \mathrm{M}$ kainate (Fig. 4) was not significantly different $(P>0.05)$. The response type of the 3 DIV cells is similar to that represented for $100 \mu \mathrm{M}$ AMPA plus CTZ (Fig. 2F), or to 14 DIV (Fig. 2H). These images are valid for all developmental stages, except for $5 \mathrm{~h}$ in vitro.

\section{4. $\mathrm{Co}^{2+}$ uptake upon NMDA receptor activation of chick retina cells during development in culture}

Stimulation of chick retina cells with $400 \mu \mathrm{M}$ NMDA, was without effect, as compared with control, on $\mathrm{Co}^{2+}$ 


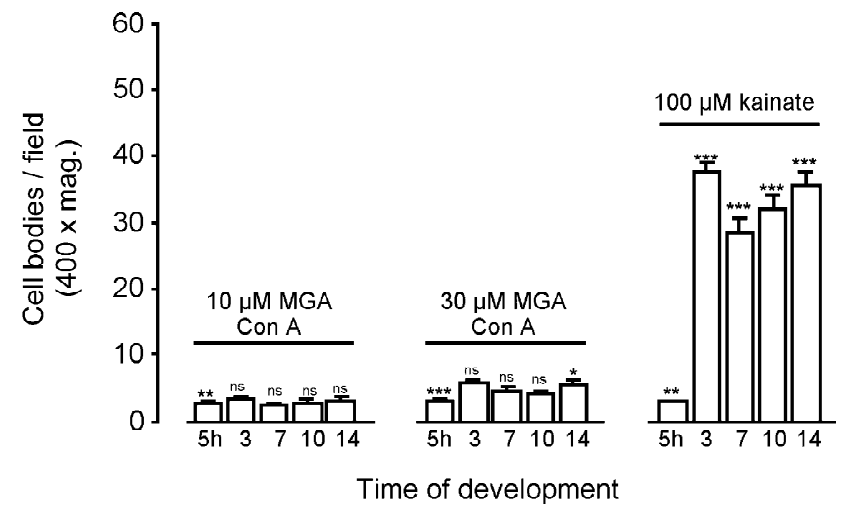

Fig. 4. Chick retina cells with cobalt positive response upon stimulation with kainate receptor agonists, during development in vitro for $5 \mathrm{~h}, 3,5$, 7, 10 and 14 days. Cobalt uptake under stimulation with $10 \mu \mathrm{M}$ MGA plus $0.3 \mathrm{mg} / \mathrm{ml}$ of Con A, $30 \mu \mathrm{M}$ MGA plus $0.3 \mathrm{mg} / \mathrm{ml}$ of Con A or 100 $\mu \mathrm{M}$ kainate was determined as described in Materials and methods. Significantly different from control in the absence of stimulation (Fig. 1), $*, P<0.05$; **, $P<0.01$ and $* * *, P<0.001$. Not significantly different from control (Fig. 1), ns.

uptake during the studied period (Fig. 5), where the response was not statistically different from the control $(P>0.05)$. We also tried stimulation with $400 \mu \mathrm{M}$ NMDA

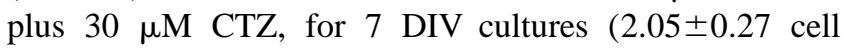
bodies/field $400 \times$ mag.), and there was no statistically significant differences, when compared to $7 \mathrm{DIV}$, in the presence of $400 \mu \mathrm{M}$ NMDA $(P>0.05)$. The $\mathrm{Co}^{2+}$ positive cells responding to NMDA, may be represented by the responses in the control for $5 \mathrm{~h}$ in vitro (Fig. 2A) or 14 DIV (Fig. 2B).

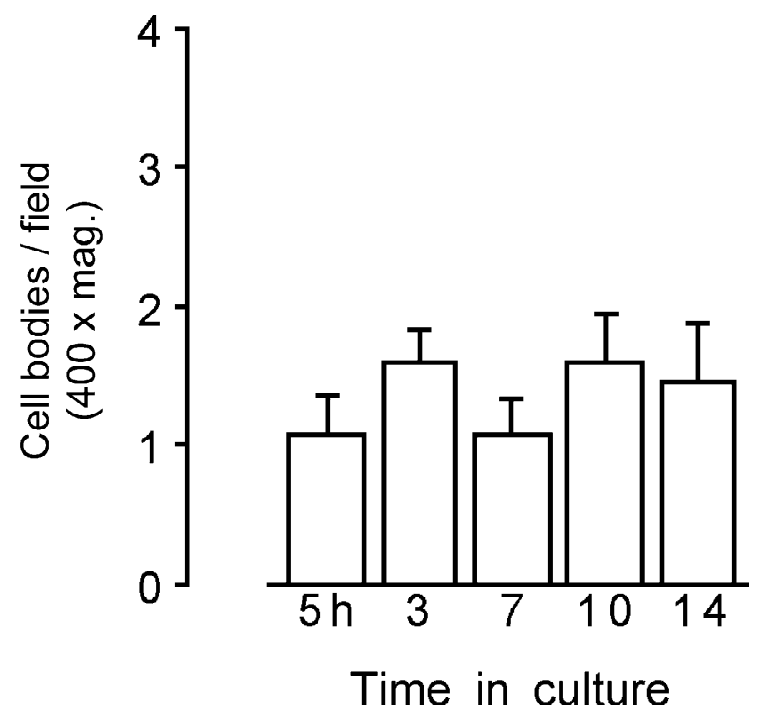

Fig. 5. Chick retina cells with cobalt positive response upon NMDA stimulation, during development in vitro for $5 \mathrm{~h}, 3,5,7,10$ and 14 days. Cobalt uptake under stimulation with $400 \mu \mathrm{M}$ NMDA was determined as described in Materials and methods.

\subsection{Expression of GluR4 subunit in chick retina cells during development in stationary culture}

We further examined the presence of GluR4 expression by immunocytochemistry, simultaneously with MAP2. (Fig. 6A-I). At $5 \mathrm{~h}$ in vitro, there were only a very few cells strongly immunolabelled for GluR4, at the perinuclear region (Fig. 6A), although at this stage there were cells already showing processes as seen with MAP2 (Fig. 6B). About the same was found at $3 \mathrm{DIV}$, as shown in Fig. $6 \mathrm{C}$, and in more detail in Fig. 6D. However, at this stage, we found cells strongly labelled both in the perinuclear region and in the neurites (Fig. 6E). The number of immunoreactive cells increased at the subsequent developmental stages (Fig. 6F-G). At these stages (7, 10 and 14 DIV) there were cells that were extremely immunoreactive at the perinuclear region. At 3 DIV there can be observed some intense punctuated labelling at the neurites (Fig. 6E), but the number of strongly punctuated structures increased at 7 DIV and at the following stages, as represented in Fig. $6 \mathrm{H}$ (for $10 \mathrm{DIV}$ ). This GluR4 punctuated labelling was observed at the neurites, as shown by double labelling with MAP2 (Fig. 6I).

\section{Discussion}

In the present study we discuss the development profiles of AMPA receptor agonist induced $\mathrm{Ca}^{2+}$ entry (mimicked by $\mathrm{Co}^{2+}$ ) of retina cells in culture, and determined the correlation of $\mathrm{Ca}^{2+}$ entry with the expression of the AMPA subunit GluR4.

\section{1. $\mathrm{Co}^{2+}$ uptake through AMPA receptors during development}

In the present work we determined that the AMPA receptors are functionally active, as followed by $\mathrm{Co}^{2+}$ uptake, in chick embryo retina cells maintained in stationary cultures for $5 \mathrm{~h}$ in vitro, after 8 days of embryonic development, although in a very small population of neurons. The number of cells permeable to $\mathrm{Co}^{2+}$ increased at $3 \mathrm{DIV}$, and this response decreased until 14 DIV, upon stimulation with $100 \mu \mathrm{M}$ AMPA, in the presence of $30 \mu \mathrm{M}$ CTZ, an inhibitor of AMPA receptor desensitisation [34]. The increase in the number of cells that respond to the agonists and accumulate $\mathrm{Co}^{2+}$ observed from $5 \mathrm{~h}$ in vitro to 3 DIV cannot be entirely due to a trypsin effect on the receptors immediately after cell dissociation, as we previously showed for calcium channels in chick retinospheroids [7]. In fact, retinospheroids derived from 11-dayold embryos and cultured for $5 \mathrm{~h}$ in vitro, show about the same $\left[\mathrm{Ca}^{2+}\right]_{\mathrm{i}}$ response to $\mathrm{KCl}$ depolarisation that is obtained for retinospheroids derived from 8-day-old embryos and cultured for 3 DIV [7]. The present results are in accordance with the activity of intracellular $\mathrm{Ca}^{2+}$ rise 

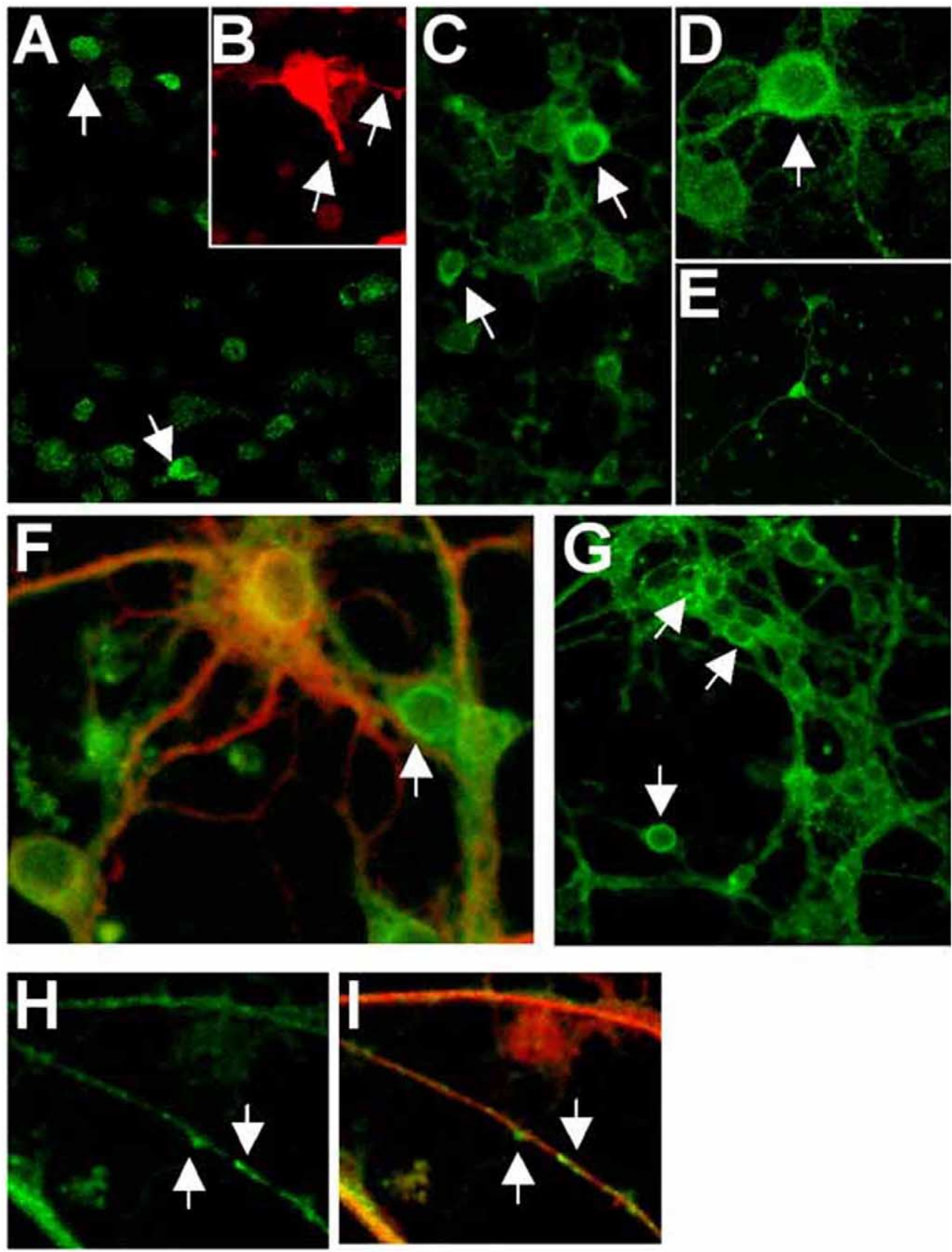

Fig. 6. Microphotographs of GluR4 and/or MAP2 immunoreactivity in chick retina cells during development in vitro for 5 h, 3, 5, 7, 10 and 14 days. (A) Cells with $5 \mathrm{~h}$ in vitro labelled for GluR4. (B) Cells with $5 \mathrm{~h}$ in vitro labelled for MAP2. (C) Cells with 3 DIV, labelled for GluR4. (D) Cells with 3 DIV, labelled for GluR4 ( $2 \times$ digital zoom). (E) Cells with 3 DIV, labelled for GluR4 (0.5 digital zoom). (F) Cells with 7 DIV, double labelled for GluR4 and MAP2 ( $2 \times$ digital zoom). (G) Cells with 10 DIV, labelled for GluR4. (H) Cells with 10 DIV, labelled for GluR4. A detail of neurites ( $2 \times$ digital zoom). (I) Same as $(\mathrm{H})$ but showing double labelling immunoreactivity for GluR4 and MAP2 ( $2 \times$ digital zoom). Photos are representative of the various conditions and the pictures magnification was $630 \times$ except when indicated otherwise.

obtained in intact retinas from chick embryo [31], since the responses to AMPA were observed from day 7 of development. These authors also observed an increase in the responses to AMPA until day 9, which then decreased until day 13 of development in the embryo, in accordance to our results, although $\mathrm{Ca}^{2+}$ entry is probably occurring mainly through the voltage sensitive calcium channels in chick retina cells, as previously shown [14]. Also, the dramatic increase in the $\mathrm{Co}^{2+}$ positive cells that we observe from 5 $\mathrm{h}$ in vitro to $3 \mathrm{DIV}$, coincides with the period of synapse formation in the embryo (E12) [18] or near the period of synapse formation in stratospheroids of chick retina (E6 plus 8 DIV) [19].

We also found that stimulation of chick retina cells in 
culture with AMPA does not cause large amounts of $\mathrm{Co}^{2+}$ uptake of the cells. However, when CTZ was present, a compound that inhibits desensitisation of AMPA receptors [34], the number of cells responding increased dramatically, specially in cells after 3 DIV (Fig. 3). These results indicate that in physiological conditions the entry of $\mathrm{Ca}^{2+}$ through the AMPA receptor, mimicked by $\mathrm{Co}^{2+}$, is very small when compared with calcium entry through the voltage sensitive calcium channels that may be activated upon AMPA stimulation [14]. This suggests that in these cells, during development, the AMPA receptors should not contribute much in a direct manner to the possible mechanisms of actin based dendritic spine modulation [16,32], or crest formation. However it is known that the $\mathrm{Ca}^{2+}$ radius is smaller then the $\mathrm{Co}^{2+}$ radius, and more $\mathrm{Ca}^{2+}$ may enter through the receptor as compared to $\mathrm{Co}^{2+}$.

\subsection{Is there $\mathrm{Co}^{2+}$ uptake through kainate receptors during development?}

We also observed that kainate can induce $\mathrm{Co}^{2+}$ uptake in chick retina cells in stationary culture, maintained for 5 $h$ in vitro ( 8 days of development), and the number of cells responding, as well as the intensity of the response, increased until $3 \mathrm{DIV}$, and remained relatively constant until 14 DIV. These results are in accordance with those obtained in intact chick retinas during development $[1,31]$, in which responses to kainate were observed at day 7 of development, and this response increased until day 9 and remained relatively constant until day 13 , during development in vivo.

In order to check whether kainate was activating kainate receptors, we used a specific kainate receptor agonist, MGA [17], and con A, which has been reported to inhibit desensitisation of the kainate receptors [33]. Our results show that there may be only few kainate receptors in these cells and, therefore the effects of kainate are probably mainly due to AMPA receptors, which do not show extensive desensitisation upon stimulation with this agonist. The results cannot be due to the higher concentration of kainate used in most of the experiments $(100 \mu \mathrm{M})$, because we obtained similar results using 30 or $100 \mu \mathrm{M}$ of kainate for 7 DIV. These results are in accordance with a previous work in which it was shown that AMPA receptors do not desensitise when activated with kainate $[5,22]$. Also, in cultured retina cells, the kainate-induced calcium increase is mainly due to the activation of AMPA receptors, since LY 303070, the selective AMPA receptor antagonist, almost completely abolishes the response to kainate [8]. Thus, in the present study, kainate is mainly activating AMPA receptors, in retina cells at different developmental stages in vitro. However we cannot rule out a small contribution of kainate receptors, since MGA significantly increased the number of $\mathrm{Co}^{2+}$ positive cells in cultures maintained for $5 \mathrm{~h}$ in vitro or $14 \mathrm{DIV}$, and we have found the expression during development of the kainate receptor subunits GluR6/7 in retinospheroids cultures (data not shown).

\section{3. $\mathrm{Co}^{2+}$ uptake upon NMDA receptor stimulation during development}

Our results clearly indicate that $\mathrm{Co}^{2+}$ does not enter through NMDA receptor, which is in accordance with previous results showing that $\mathrm{Co}^{2+}$ only enter through nonNMDA receptors [28]. However, NMDA may be inducing the release of glutamate in chick retina cells as we have observed for retinospheroids (data not shown), and in these conditions we could activate AMPA receptors. In order to check whether this was the case, we stimulated these monolayer cultures (with 7 DIV) with NMDA, in the presence and in the absence of CTZ. We did not find any statistical significant difference, indicating that the amount of glutamate release may not be enough to activate the AMPA receptors in these conditions.

\subsection{Correlation between localisation of GluR4 and $\mathrm{Co}^{2+}$ uptake}

In the chick retina cells in culture we observed the presence of GluR4 AMPA receptor subunit from a period early in development, and in parallel with the uptake of $\mathrm{Co}^{2+}$. We found that even as early as $5 \mathrm{~h}$ in vitro there was a population of cells strongly immunoreactive for GluR4. The number of these cells increased until 3 DIV, and at this time of development we observed that the main reactive area in the cells was the perinuclear region, although there was also some GluR4 immunoreactivity in the dendrites. This explains the fact that upon strong stimulation with kainate, or with $100 \mu \mathrm{M}$ AMPA or with $500 \mu \mathrm{M}$ glutamate, in the presence of $\mathrm{CTZ}$, the uptake of $\mathrm{Co}^{2+}$ occurred at the perinuclear region, as well as at the dendrites. In contrast, while with less intense stimuli (10 $\mu \mathrm{M}$ AMPA plus CTZ or $100 \mu \mathrm{M}$ AMPA or $500 \mu \mathrm{M}$ glutamate or NMDA), the uptake of $\mathrm{Co}^{2+}$ was restricted mainly to the perinuclear region. At $7 \mathrm{DIV}$, the population of cells highly labelled for GluR4 at the perinuclear region stabilises, as well as the labelling for GluR4 at the dendrites, which is smaller as compared with the labelling at the neurites, and stabilises at this time, in accordance with the time for synapse formation in stratospheroids of chick retina [19]. These results explain the fact that from 7 DIV until 14 DIV, potent stimuli, (kainate, or $100 \mu \mathrm{M}$ AMPA or $10 \mu \mathrm{M}$ AMPA or $500 \mu \mathrm{M}$ glutamate, in the presence of CTZ or 10 $\mu$ M AMPA plus CTZ) induce $\mathrm{Co}^{2+}$ uptake by cells both at the dendrites and at the perinuclear region. In contrast, at the same developmental stages, weaker stimuli (NMDA, glutamate, AMPA) induced $\mathrm{Co}^{2+}$ uptake exclusively at the perinuclear region (where there is a higher concentration of GluR4). Immunoreactivity of GluR4 is in accordance with previous work on cat retina where it is shown that GluR4 is mainly in A-horizontal cells and AII amacrine cells with 
highly labelled cell bodies [29]. In contrast, in rat and goldfish retina, GluR4 was found in Müller glial cells [27].

In conclusion, the present study demonstrates that $\mathrm{Co}^{2+}$ uptake in chick retina cells during development in vitro is mainly due to $\mathrm{Co}^{2+}$ entry through AMPA receptors, especially in conditions where the AMPA receptors do not desensitise. Furthermore, the effects of kainate on $\mathrm{Co}^{2+}$ uptake were probably mainly due to activation of AMPA receptors, for the development stages investigated. Furthermore, we report the expression of GluR4 during development and found that this AMPA receptor subunit is extremely concentrated at the perinuclear area in a population of cells. Moreover, the GluR4 expression increases during development mainly until 7 DIV. The same occurs at the neurites but the GluR4 labelling is smaller as compared with the perinuclear region. Also, the localisation of GluR4 is well correlated with the $\mathrm{Co}^{2+}$ entry, since the most stained area of the cell with $\mathrm{Co}^{2+}$ is the perinuclear area, also the most labelling with GluR4. Only after 3 DIV and with strong stimuli did the cells become $\mathrm{Co}^{2+}$ positive at the neurites.

\section{Acknowledgements}

We thank Professor A.P. Carvalho and Professor C.B. Duarte for helpful discussions during this work. This work was supported by Fundação para a Ciência e Tecnologia, through Program PRAXIS XXI (2/2.1/BIA/126/94), Portugal.

\section{References}

[1] S. Allcorn, M. Catsicas, P. Mobbs, Developmental expression and self-regulation of $\mathrm{Ca}^{2+}$ entry via AMPA/KA receptors in the embryonic chick retina, Eur. J. Neurosci. 8 (1996) 2499-2510.

[2] R. Balazs, N. Hack, O.S. Jorgensen, Stimulation of the $N$-methyl-Daspartate receptor has a trophic effect on differentiating cerebellar granule cells, Neurosci. Lett. 87 (1988) 80-86.

[3] B. Bettler, C. Mulle, Neurotransmitter receptors. 2. AMPA and kainate receptors, Neuropharmacology 34 (1995) 123-139.

[4] C.F. Bigge, Ionotropic glutamate receptors, Curr. Opin. Chem. Biol. 3 (1999) 441-447.

[5] D. Bleakman, D. Lodge, Neuropharmacology of AMPA and kainate receptors, Neuropharmacology 37 (1998) 1187-1204.

[6] J. Boulter, M. Hollmann, A. O'Shea-Greenfield, M. Hartley, E. Deneris, C. Maron, S. Heinemann, Molecular cloning and functional expression of glutamate receptor subunit genes, Science 249 (1990) 1033-1037.

[7] A. Capela, A. Cristóvão, C. Carvalho, A.P. Carvalho, Ontogeny of the L-type voltage sensitive calcium channels in chick embryo retinospheroids, Brain Res. Dev. Brain Res. 104 (1997) 63-69.

[8] A.L. Carvalho, C.B. Duarte, C.J. Faro, A.P. Carvalho, E.V. Pires, Calcium influx through AMPA receptors and through calcium channels is regulated by protein kinase $\mathrm{C}$ in cultured retina amacrine-like cells, J. Neurochem. 70 (1998) 2112-2119.

[9] A.L. Carvalho, K. Kameyama, R.L. Huganir, Characterization of phosphorylation sites on the glutamate receptor 4 subunit of the AMPA receptors, J. Neurosci. 19 (1999) 4748-4754.
[10] D.W. Choi, Glutamate neurotoxicity and diseases of the nervous system, Neuron 1 (1988) 623-634.

[11] A.J. Cristóvão, A.N. Capela, C.M. Carvalho, $\mathrm{Ca}^{2+}$ stores in the chick embryo retina cells, Cell Signal 9 (1997) 97-103.

[12] R. Dingledine, K. Borges, D. Bowie, S.F. Traynelis, The glutamate receptor ion channels, Pharmacol. Rev. 51 (1999) 7-61.

[13] C.B. Duarte, I.L. Ferreira, P.F. Santos, A.L. Carvalho, P.M. Agostinho, A.P. Carvalho, Glutamate in life and death of retinal amacrine cells, Gen. Pharmacol. 30 (1998) 289-295.

[14] C.B. Duarte, P.F. Santos, A.P. Carvalho, $\left[\mathrm{Ca}^{2+}\right]_{i}$ regulation by glutamate receptor agonists in cultured chick retina cells, Vis. Res. 36 (1996) 1091-1102.

[15] C.B. Duarte, P.F. Santos, J. Sanchez-Prieto, A.P. Carvalho, Glutamate release evoked by glutamate receptor agonists in cultured chick retina cells-modulation by arachidonic acid, J. Neurosci. Res. 44 (1996) 363-373.

[16] M. Fischer, S. Kaech, U. Wagner, H. Brinkhaus, A. Matus, Glutamate receptors regulate actin-based plasticity in dendritic spines, Nature Neurosci. 3 (2000) 887-894.

[17] Z.Q. Gu, D. Hesson, J. Pelletier, M.L. Maccechini, L.M. Zhou, P. Skolnick, Synthesis, resolution, and biological evaluation of the four stereoisomers of 4-methylglutamic acid: selective probes for kainate receptors, J. Med. Chem. 38 (1995) 2518-2520.

[18] H. Hering, S. Kroger, Formation of synaptic specializations in the inner plexiform layer of the developing chick retina, J. Comp. Neurol. 375 (1996) 393-405.

[19] H. Hering, S. Kroger, Synapse formation and agrin expression in stratospheroid cultures from embryonic chick retina, Dev. Biol. 214 (1999) 412-428.

[20] M. Hollmann, S. Heinemann, Cloned glutamate receptors, Annu. Rev. Neurosci. 17 (1994) 31-108.

[21] M. Hollmann, A. O'Shea-Greenfield, S.W. Rogers, S. Heinemann, Cloning by functional expression of a member of the glutamate receptor family, Nature 342 (1989) 643-648.

[22] J.B. Jensen, A. Schousboe, D.S. Pickering, Development of calciumpermeable $\alpha$-amino-3-hydroxy-5-methyl-4-isoxazolepropionic acid receptors in cultured neocortical neurons visualized by cobalt staining, J. Neurosci. Res. 54 (1998) 273-281.

[23] A. Matus, Postsynaptic actin and neuronal plasticity, Curr. Opin. Neurobiol. 9 (1999) 561-565.

[24] E. Meier, L. Hertz, A. Schousboe, Neurotransmitters as developmental signals, Neurochem. Int. 19 (1991) 1-15.

[25] N. Nakanishi, N.A. Shneider, R. Axel, A family of glutamate receptor genes: evidence for the formation of heteromultimeric receptors with distinct channel properties, Neuron 5 (1990) 569581.

[26] T. Paperna, Y. Lamed, V.I. Teichberg, cDNA cloning of chick brain $\alpha$-amino-3-hydroxy-5-methyl-4-isoxazolepropionic acid receptors reveals conservation of structure. Function and post-transcriptional processes with mammalian receptors, Mol. Brain Res. 36 (1996) $101-113$

[27] Y.W. Peng, C.D. Blackstone, R.L. Huganir, K.W. Yau, Distribution of glutamate receptor subtypes in the vertebrate retina, Neuroscience 66 (1995) 483-497.

[28] R.M. Pruss, R.L. Akeson, M.M. Racke, J.L. Wilburn, Agonistactivated cobalt uptake identifies divalent cation-permeable kainate receptors on neurons and glial cells, Neuron 7 (1991) 509-518.

[29] P. Qin, R.G. Pourcho, AMPA-selective glutamate receptor subunits GluR2 and GluR4 in the cat retina: An immunocytochemical study, Visual Neurosci. 16 (1999) 1105-1114.

[30] P.H. Seeburg, The TiPS/TINS lecture: the molecular biology of mammalian glutamate receptor channels, Trends Pharmacol. Sci. 14 (1993) 297-303.

[31] M. Sugioka, Y. Fukuda, M. Yamashita, Development of glutamateinduced intracellular $\mathrm{Ca}^{2+}$ rise in the embryonic chick retina, J. Neurobiol. 34 (1998) 113-125.

[32] D. Van Rossum, U.K. Hanisch, Cytoskeletal dynamics in dendritic 
spines: direct modulation by glutamate receptors?, Trends Neurosci. 22 (1999) 290-295.

[33] L.A. Wong, M.L. Mayer, Differential modulation by cyclothiazide and concanavalin A of desensitization at native-amino-3-hydroxy-5methyl-4-isoxazolepropionic acid-and kainate-preferring glutamate receptors, Mol. Pharmacol. 44 (1993) 504-510.

[34] K.A. Yamada, C.M. Tang, Benzothiadiazides inhibit rapid glutamate receptor desensitization and enhance glutamatergic synaptic currents, J. Neurosci. 13 (1993) 3904-3915.
[35] J.J. Zhu, J.A. Esteban, Y. Hayashi, R. Malinow, Postnatal synaptic potentiation: delivery of GluR4-containing AMPA receptors by spontaneous activity, Nature Neurosci. 3 (2000) 1098-1106.

[36] C.F. Zorumski, L.L. Thio, Properties of vertebrate glutamate receptors: calcium mobilization and desensitization, Prog. Neurobiol. 39 (1992) 295-336. 